\title{
Acute lesions of primary visual cortical areas in adult cats inactivate responses of neurons in higher visual cortices
}

\author{
ZHANG Hui ${ }^{1}$, MENG Jian-Jun ${ }^{1}$, WANG Ke ${ }^{1}$, LIU Rui-Long ${ }^{1}$, XI Min-Min ${ }^{2}$, HUA Tian-Miao ${ }^{1{ }^{*}}$ \\ (1. School of Life Science, Anhui Normal University, Wuhu Anhui 241000, China; 2. Management School, Queen's University, Belfast, UK )
}

\begin{abstract}
Psychophysical studies suggest that lateral extrastriate visual cortical areas in cats may mediate the sparing of vision largely by network reorganization following lesions of early visual cortical areas. To date, however, there is little direct physiological evidence to support this hypothesis. Using in vivo single-unit recording techniques, we examined the response of neurons in areas 19, 21, and 20 to different types of visual stimulation in cats with or without acute bilateral lesions in areas 17 and 18. Our results showed that, relative to the controls, acute lesions inactivated the response of $99.3 \%$ of neurons to moving gratings and $93 \%$ of neurons to flickering square stimuli in areas 19,21 , and 20 . These results indicated that acute lesions of primary visual areas in adult cats may impair most visual abilities. Sparing of vision in cats with neonatal lesions in early visual cortical areas may result largely from a postoperative reorganization of visual pathways from subcortical nucleus to extrastriate visual cortical areas.
\end{abstract}

Key words: Acute lesion; Primary visual cortical areas; Neuronal response; Areas 19, 21 and 20

\section{急性毁损猫的初级视区使高级视区细胞失去对视觉刺激的诱发反应}

\author{
张 辉 ${ }^{1}$, 孟建军 ${ }^{1}$, 王 珂 ${ }^{1}$, 刘瑞龙 ${ }^{1}$, 奚敏敏 ${ }^{2}$, 华田苗 ${ }^{1, *}$ \\ (1. 安徽师范大学 生命科学学院, 安徽 芜湖 $241000 ; 2$. 英国皇后大学 管理学院, 贝尔法斯特)
}

摘要: 心理物理学研究提示, 初级视区毁损后的视觉残留可能是通过外纹状皮层的神经网络重组介导的, 但缺 少支持这一假说的电生理实验证据。采用在体细胞外单细胞记录技术, 该研究分别检测了初级视区 (主要包括 17 和 18 区) 急性毁损猫和正常对照猫的高级视区（包括 19、20 和 21 区）神经元对不同视觉刺激的反应性。结果 显示, 与对照相比, 急性毁损初级视区使 $99.3 \%$ 的高级视区神经元丧失对运动光栅刺激的诱发反应, $93 \%$ 的神经元 丧失对闪光刺激的反应。该结果表明, 急性毁损成年猫的初级视皮层可能会导致其绝大部分视觉能力丧失。在幼 年期实施初级视皮层毁损后, 成年猫出现的残留视觉可能主要是由于手术后皮层下神经核团与外纹状皮层之间的 通路重组引起的。

关键词: 急性毁损; 初级视区; 神经元反应; 19、20、21区

中图分类号: Q436; Q429+2; Q421; Q424 文献标志码：A＼cjkstart文章编号：0254-5853-(2012)02-0218-07

It is widely believed that vision in human and higher-order mammals is mediated through the pathway from retina to lateral geniculate nucleus (LGN) and then to the primary visual cortex (Chino et al, 1992; Girard \& Bullier, 1989; Hubel \& Wiesel, 1962), and sensory inputs to the higher order cortical areas come from the primary visual cortical areas. However, subjects with complete damage to the primary visual cortical areas still show above chance performance in some visual tasks, though generally lacking conscious perception (Barbur et al, 1980; Cowey \& Stoerig, 1991, 1995, 1997; Moore et al, 1995; Stoerig \& Cowey, 1997, 2007; Tong, 2003). This post-lesion residual vision, called blindsight, may be mediated by parallel V1 bypassing connections between subcortical nucleus and higher visual cortical areas. So far, however, the possible subcortical and

Received date: 2011-12-08; Accepted date: 2012-01-08

Foundation items: National Natural Science Foundation of China (31171082); Natural Science Foundation of Anhui Province (070413138); Key Research Foundation of Anhui Province Education Department (KJ2009A167)

*Corresponding author (通信作者), E-mail: tianmiaohua@gmail.com

收稿日期：2011-12-08; 接受日期：2012-01-08 
extrastriate locations involved in this parallel visual processing pathways are largely unclear (Chino et al, 1992; Collins et al, 2005; Girard et al, 1992; Goebel et al, 2001; Moore et al, 2001; Rosa et al, 2000; Rossion et al, 2000; Schoenfeld, 2002). Moreover, it is unknown whether the residual vision is a property of the network that already exists but is uncovered only after removal of inputs from the primary visual cortex (Schmid et al, 2009; Smirnakis et al, 2005), or whether it is the result of plastic reorganization that develops over time in specific areas after the lesions of primary visual cortical areas (Baseler et al, 1999; Bridge et al, 2008; Eysel et al, 1999; Huxlin, 2008; Illig et al, 2000; Payne et al, 1996; Poggel et al, 2006; Silvanto et al, 2007; Zepeda et al, 2004) .

Some psychophysical experiments show that cats with lesions confined to areas 17, 18, and part of 19 made in infancy show more sparing of function in task performance of visual cliff detection and orienting to targets suddenly appearing in the visual field (Shupert et al, 1993). However, cats with lesions in areas 17, 18, 19 and suprasylvian visual areas were severely impaired at all visual tasks whether the lesions were incurred neonatally or in adulthood (Rushmore \& Payne, 2004; Shupert et al, 1993). These findings suggest that the higher visual cortices, including areas 19, 21, and 20, are likely involved in the sparing of vision after lesions of early visual cortical areas, and such sparing of vision is enhanced through plastic reorganization after neonatal lesion (Rushmore \& Payne, 2004; Shupert et al, 1993). To further test this hypothesis, we used single-unit extracellular recording techniques to record the neuronal response to visual stimulation in areas 19, 21, and 20 of anesthetized normal adult cats and cats with acute lesions of areas 17 and 18. By an unbiased statistical comparison, we determined to what extent acute lesions of primary visual cortical areas affected the responsiveness of neurons in areas 19, 21, and 20.

\section{Materials and Methods}

\subsection{Subjects}

Eight healthy young adult cats (2-3 a) were studied. All cats were examined ophthalmoscopically before the experiment to confirm that no optical or retinal problems impaired their visual function. All experiment procedures were strictly in accordance with the National Institutes Health Guide for the Care and Use of Laboratory Animals. 1.2 Preparation for electrophysiology recording

All cats were prepared for extracellular single-unit or multi-units recording as previously described (Hua et al, 2006, 2009, 1010; Peng et al, 2011; Zhou et al, 2011). Briefly, anesthesia was induced by injection (i.m.) of ketamine $\mathrm{HCl}$ (40 mg/kg body weight, i.m.) and xylazine (2 $\mathrm{mg} / \mathrm{kg}$ body weight, i.m.). After intubation of intravenous and tracheal cannulae, the cats were immobilized in stereotaxic apparatus with ear bars, eye bars, and a bite bar. Pupils were maximally dilated with atropine $(1 \%)$, and appropriate contact lenses were used after optical refraction correction for both eyes. Neosynephrine (5\%) was administered to retract the nictitating membranes. Glucose (5\%)-saline (0.9\%) solution containing a mixture of urethane $(20 \mathrm{mg} / \mathrm{h} / \mathrm{kg}$ body weight) and gallamine triethiodide $(10 \mathrm{mg} / \mathrm{h} / \mathrm{kg}$ body weight) was infused intravenously to keep the animal anesthetized and paralyzed. Expired $\mathrm{pCO}_{2}$ was maintained at approximately $3.8 \%$. Heart rate (180-220 pulses/min) and EKG were monitored throughout the experiment to assess the level of anesthesia and ensure the subjects were not responsive to any pain. The skull and dura over unilateral areas 19, 21, and 20 were removed with a fine surgery under light microscope. Single- or multi-unit recordings were performed using a glass microelectrode (with an impedance of 3-5 $\mathrm{m} \Omega$ ) positioned vertically to the cortical surface and driven by a hydraulic micromanipulator (NARISHIGE, Japan). After the preparation was complete, the optic discs of the two eyes were reflected onto a movable transparent tangent screen that was positioned $57 \mathrm{~cm}$ from the retina and overlapped with the CRT monitor used for stimulus presentation. Area centralis of each eye was located prior to physiological recording based on the position of the optic discs reflected onto the tangent screen (Bishop et al, 1962).

\subsection{Visual stimuli}

To maximally evoke visual response in areas 19, 21, and 20 , we used two types of visual stimuli, including flickering squares and moving sinusoidal gratings with optimal orientation as well as temporal and spatial frequencies. Stimuli were shown on a CRT monitor (resolution $1024 \times 768$, refresh rate 85 ) positioned $57 \mathrm{~cm}$ from the animal's eyes. The program to generate the stimuli was written in MATLAB, using extensions provided by the high-level Psychophysics Toolbox (Brainard, 1997) and low-level VideoToolbox (Pelli, 1997). Once spontaneous activity was detected, the cell's receptive field center was carefully located by consecutively presenting a series of computer-generated 
flickering light squares on the CRT. An ophthalmoscope and a hand held projector were also used to assist in mapping the receptive field center. The cell's response to different types of visual stimuli (last for less than $5 \mathrm{~s}$ ) was systematically recorded. Each stimulus was presented to both eyes and repeated 4-6 times with a 1min interval between each trial for functional recovery of the recorded cell. Before each stimulus was presented, spontaneous activity was acquired during a $1 \mathrm{~s}$ period while no stimulus was shown on the screen.

The contrast of each stimulus used was set at $100 \%$. The mean luminance of the display was $19 \mathrm{~cd} / \mathrm{m}^{2}$ and the environmental ambient luminance on the cornea was 0.1 lux.

\subsection{Lesion surgery}

Four randomly selected cats received acute bilateral lesions in areas 17 and 18 on marginal and posterolateral gyri before electrophysiological recording in areas 19, 21, and 20 (Fig.1A). All surgical procedures were similar to those described previously (Hua et al, 2009; Mao et al, 2011; Zhou et al, 2011). Briefly, cats were adequately anesthetized prior to preparation for single- or multi-unit recording, and the skull over the marginal and posterolateral gyri were maximally exposed and removed with a scalpel. Bilateral areas 17 and 18 on marginal and posterolateral gyri were then completely lesioned with an aspirating needle attached to a vacuum pump. The operation was carefully performed under light microscopy to ensure that the middle and post suprasylvian gyri as well as the white matter under marginal and posterolateral gyri were not damaged.

\subsection{Histology}

After electrophysiological recording, animals were anesthetized deeply with ketamine $\mathrm{HCl}(80 \mathrm{mg} / \mathrm{kg}$ body weight) and xylazine (6 mg/kg body weight) and then perfused through the heart with $1000 \mathrm{~mL}$ of saline solution, followed by $500 \mathrm{~mL}$ of fixative solution containing $2 \%$ paraformaldehyde in $0.1 \mathrm{~mol} / \mathrm{L}$ phosphate buffer (PB). Brains were extracted, photographed with a high resolution camera, post-fixed in $4 \%$ paraformaldehyde in $0.1 \mathrm{~mol} / \mathrm{L}$ PBS for $24 \mathrm{~h}$, and stored in $30 \%$ sucrose in $0.1 \mathrm{~mol} / \mathrm{L} \mathrm{PBS}$ at $4{ }^{\circ} \mathrm{C}$. After the tissue was infiltrated by the sucrose solution, it was sectioned frozen at $40 \mu \mathrm{m}$ in the coronal plane. A series of sections at $200 \mu \mathrm{m}$ intervals were stained for Nissl substance, which were used to examine if the lesions were successfully performed.
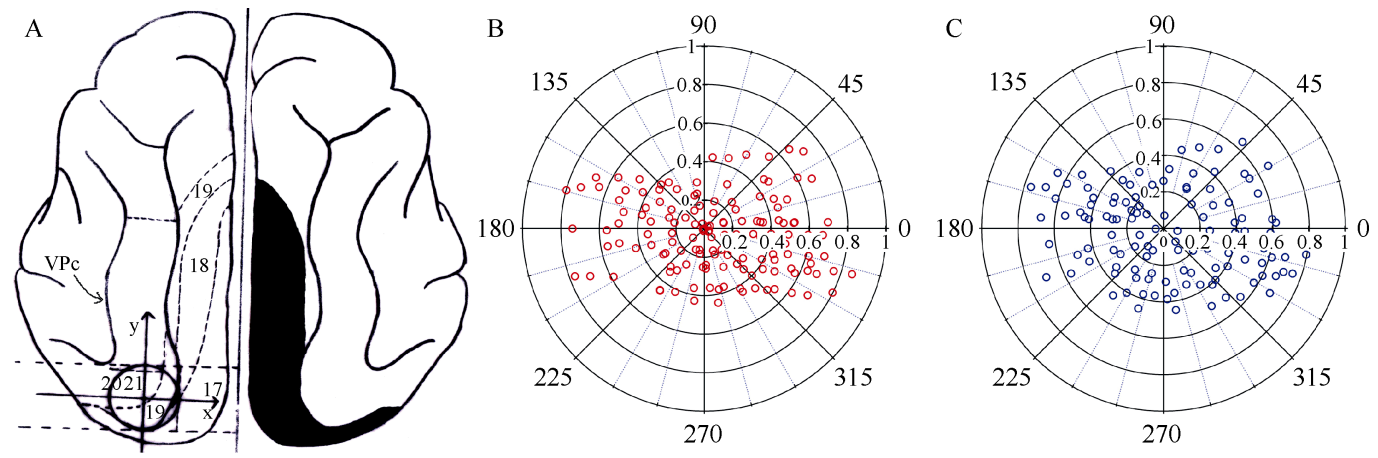

Fig. 1 Overview of the main gyri and sulcus in the visual cortex of cats and the cortical lesion and recording areas

A) Demonstration of the lesion surgery location (solid black areas, including chiefly areas 17 and 18) and electrophysiological recording areas within areas 19, 21 and 20. We photographed the whole visual cortex and set in the picture a planar reference axis between two parallel lines that were perpendicular to the midline and passed by the rear tip of visuoparietal cortex and middle suprasylvian sulcus respectively. The electrode penetration locations in area 19,21 and 20 were then normalized to a standard circle with a radius of 1; B\&C) Showing the distribution of electrode penetrations in areas 19,21 and 20 in cats with (C) and without (B) lesions. The site of each penetration was marked in the picture using blood vessels on the cortical surface as a reference and assigned a value of radius from the point 0 and angle on a $360^{\circ}$ scale in the reference axis.

\subsection{Data acquisition and analysis}

After the response of isolated units was amplified with a microelectrode amplifier (NIHON KOHDEN, Japan) and differential amplifier (Dagan 2400A, USA), action potentials were fed into a window discriminator with an audio monitor. The original voltage traces were digitized using an acquisition board (National Instruments,
USA) controlled by IGOR (WaveMetrics, USA), and saved for later analysis. Cell response to each visual stimulus type was defined as the mean firing rate (spontaneous activity subtracted) corresponding to the time of stimulus modulation. An ANOVA was used to determine whether the firing rates during the stimulus presentation exceeded the firing rates during the pre- 
stimulus period. The proportion of cells with significant visually-evoked responses in cats with or without lesions was counted and calculated as cells per penetration of electrode.

To examine if the electrode penetration distribution patterns were similar in cats with or without primary visual cortical area lesions, we photographed the whole visual cortex and marked in the picture each electrode penetration site using blood vessels on the cortical surface as a reference. After recording, we set in the picture a planar reference axis between two parallel lines that were perpendicular to the midline and passed by the rear tip of visuoparietal cortex and middle suprasylvian sulcus, respectively (Fig.1A). The electrode penetration locations in areas 19,21 and 20 were then normalized to a standard circle with a radius of 1 . Each penetration site was assigned a value of distance from point 0 and an angle on a $360^{\circ}$ scale. Data from different groups of cats were pooled into one polar plot (Fig. 1B,C).

All values were expressed as Mean $\pm S D$. Differences in cell sample distribution patterns and the proportion of cells with visually-evoked responses between different groups of cats were assessed using Chi-square test and Mann-Whitney U nonparametric test.

\section{Results}

\subsection{Electrode penetrations in cats with and without lesions}

We recorded the visually-evoked response of 499 cells from 149 electrode penetrations within areas 19, 21 and 20 in cats with no cortical lesions, and 30 cells from 120 electrode penetrations in cats with acute lesions in areas 17 and 18 (Tab. 1-3). The Chi-square test indicated that electrode penetration distribution patterns in cats with primary visual cortex lesions did not differ significantly from that in cats without lesions (Fig. 1B,C). Based on the measurements from the reference axis (see Materials and methods), the electrode penetration distribution patterns in different quadrants showed no significant differences between cats with and without lesions $\left[\chi^{2}(7)=3.701, P=0.813\right]$ (Tab.1). The electrode penetration distribution in different ranges of radius to point 0 also showed no significant differences between cats with and without lesions $\left[\chi^{2}(4)=1.070, P=0.899\right]$ (Tab.2). Further, the electrode penetration distribution in different ranges of radius to point 0 at each quadrant in cats with cortical lesions showed no significant differences from that in cats without lesions $\left[0-90^{\circ}: \chi^{2}(3)=5.891\right.$,
Tab. 1 Electrode penetration distribution in different quadrants (on a $0-360^{\circ}$ scale) of the reference axis constructed at the recording areas 19, 21 and 20 in cats with and without lesions of primary visual cortical areas

\begin{tabular}{ccc}
\hline $\begin{array}{c}\text { Quadrants } \\
\text { (Degree range) }\end{array}$ & $\begin{array}{c}\text { Electrode penetrations } \\
\text { (No lesion) }\end{array}$ & $\begin{array}{c}\text { Electrode penetrations } \\
\text { (Lesion) }\end{array}$ \\
\hline $0-45^{\circ}$ & 25 & 13 \\
$45-90^{\circ}$ & 7 & 11 \\
$90-135^{\circ}$ & 11 & 7 \\
$135-180^{\circ}$ & 22 & 24 \\
$180-225^{\circ}$ & 15 & 13 \\
$225-270^{\circ}$ & 15 & 13 \\
$270-315^{\circ}$ & 17 & 14 \\
$315-360^{\circ}$ & 37 & 25 \\
Total & 149 & 120 \\
\hline
\end{tabular}

Electrode penetration distribution in different quadrants in cats with lesions showed no significant differences with control cats $(P>0.05)$.

Tab. 2 Electrode penetration distribution in different ranges of radius from 0 point of the reference axis constructed at the recording areas 19, 21 and 20 in cats with and without lesions of primary visual cortex

\begin{tabular}{ccc}
\hline $\begin{array}{c}\text { Radius } \\
\text { range }\end{array}$ & $\begin{array}{c}\text { Electrode penetrations } \\
\text { (No lesion) }\end{array}$ & $\begin{array}{c}\text { Electrode penetrations } \\
\text { (Lesion) }\end{array}$ \\
\hline $0-0.2$ & 24 & 17 \\
$0.2-0.4$ & 53 & 45 \\
$0.4-0.6$ & 48 & 40 \\
$0.6-0.8$ & 23 & 18 \\
$0.8-1$ & 1 & 0 \\
\hline Total & 149 & 120 \\
\hline
\end{tabular}

Electrode penetration distribution in different quadrants in cats with lesions showed no significant differences with control cats $(P>0.05)$.

Tab. 3 Penetrations with cells responding to visual stimulation (PTV) and the number of cells responding respectively to flickering squares (RTF) and moving gratings (RTG) in cats without (Cat1, Cat2, Cat3, and Cat4) or with (Cat5, Cat6, Cat7, and Cat8) lesions of primary visual cortical areas

\begin{tabular}{ccccccccc}
\hline \multicolumn{3}{c}{ No lesion } & & & \multicolumn{5}{c}{ Lesion } \\
\cline { 1 - 4 } \cline { 7 - 9 } Subjects & PTV & RTF & RTG & & Subjects & PTV & RTF & RTG \\
\hline Cat1 & 21 & 61 & 62 & & Cat5 & 3 & 11 & 1 \\
Cat2 & 28 & 75 & 28 & & Cat6 & 5 & 6 & 2 \\
Cat3 & 30 & 201 & 178 & & Cat7 & 4 & 6 & 0 \\
Cat4 & 29 & 145 & 231 & & Cat8 & 3 & 4 & 0 \\
Total & 108 & 482 & 499 & & Total & 15 & 27 & 3 \\
\hline
\end{tabular}

Penetrations with cells responding to visual PTV and the number of cells responding to RTF and RTG in cats with cortical lesions were significantly smaller than in control cats $(P<0.05)$. 
$P=0.117 ; 90-180^{\circ}: \chi^{2}(3)=2.433, P=0.488 ; 180-270^{\circ}$ : $\left.\chi^{2}(3)=0.343, P=0.952 ; 270-360^{\circ}: \chi^{2}(4)=2.163, P=0.706\right]$.

2.2 Penetrations with cells responding to visual stimulation

Results showed that 108/149 (72.5\%) electrode penetrations had neurons responding to visual stimulation in cats without cortical lesions. However, only 15/120 $(12.5 \%)$ penetrations had neurons responding to visual stimulation in cats with primary visual cortex lesions. The Mann-Whitney U nonparametric test indicated that electrode penetrations of neurons responding to visual stimulation in cats with cortical lesions was significantly less than that in cats without lesions $(P<0.05)$ (Tab.3). Similarly, the average number of cells per penetration with visually-evoked responses in cats with cortical lesions was also significantly smaller than in cats without lesions $(P<0.05)$.

\subsection{Cells responding to different types of visual stimuli}

To examine whether acute lesions of primary visual cortices affected neuronal responses equally to different types of visual stimuli, we compared the proportion of neurons responding to flickering squares and moving sinusoidal gratings between cats with and without lesions.

Among the recorded neurons, 96.2\% (509/529) of neurons responded to flickering squares, 91.1\% (482/529) of neurons responded to both types of visual stimuli, and $3.8 \%(20 / 529)$ of neurons responded only to moving gratings. Relative to cats without lesions, 93\% of neurons (normalized to same electrode penetrations) in cats with acute primary visual cortex lesions failed to respond to flickering squares, while $99.3 \%$ of neurons lost responsiveness to moving gratings. The MannWhitney $U$ nonparametric test indicated that the number of cells responding to flickering squares in cats with cortical lesions was significantly decreased compared with that in the controls $(P<0.05)$ (Tab.3). Similarly, the number of cells responding to moving gratings in cats with cortical lesions was also significantly smaller than in the controls $(P<0.05)$ (Tab.3). Additionally, relative to cats without lesions, the average reduction ratio of cells responding to moving gratings (99.3\%) was not significantly different from that to flickering squares $(93 \%)$ in cats with cortical lesions $(P=0.08)$.

\section{Discussion}

Psychophysical investigations in human and primates indicate that complete damage of primary visual cortical areas can severely impair visual functions, but the patients still show certain perception when performing such visual tasks as luminance contrast detection and motion direction discrimination (Barbur et al, 1980; Cowey, 1962; Cowey \& Stoerig, 1995; Mohler \& Wurtz, 1977; Stoerig \& Cowey, 1997; Weiskrantz et al, 1974; Weiskrantz, 2004; Zeki \& Ffytche, 1998). This residual visual capacity (blindsight) could be caused by: 1) effects of direct projection from subcortical nucleus (such as lateral geniculate nucleus and superior colliculus) to higher visual cortical areas; and or 2) post-lesion reorganization of pathways from subcortical level to visual cortical regions. To clarify these possibilities, we examined the response of neurons in the higher visual cortical areas 19, 21 and 20 after acute bilateral ablation of areas 17 and 18. Our results showed that acute primary visual cortex lesions inactivated the response of most neurons in areas 19, 21 and 20 to visual stimulation of either moving grating or flickering squares. This result is consistent with previous physiology experiments done in monkeys, which reported that acute lesions or cooling of V1 could inactivate about $95 \%$ of neurons in V2, V3 and V4 (Girard \& Bullier, 1989; Girard et al, 1991a, b; Kaas et al, 1990; Schiller \& Malpeli, 1977). Therefore, our results provide physiological evidence that acute damage of primary visual cortical areas in adult cats will severely impair visual functions, as observed in previous psychophysical experiments (Shupert et al, 1993). However, cats with neonatal lesions of primary visual cortices (including chiefly areas 17 and 18) showed more sparing of vision in performance of visual cliff detection, orienting to suddenly appearing targets, and other visual tasks (Rushmore \& Payne, 2004; Shupert et al, 1993;). These residual visual functions are likely mediated through plastic reorganization of visual pathways after lesions (Payne, 2004; Rushmore and Payne, 2004; Rushmore et al, 2008; Schoenfeld et al, 2002), as demonstrated by previous morphological studies on post-lesion rewiring of visual circuits capable of mediating visual abilities (Kalil et al, 1991; Lomber et al, 1993, 1995; Payne\& Lomber, 1998). Previous research found that a significant portion of neurons in posteromedial lateral suprasylvian (PMLS) cortex were responsive to moving gratings as well as simple and complex random dot kinematograms (RDKs) following early lesions of primary visual cortex in cats (Ouellette et al, 2007). This is consistent with other observations done in primates, which showed that neurons in the lesion-projection zones of MT (middle 
temporal area) and even V2, V3 and V4 can be activated by visual stimulation after damage of primary visual cortex (Azzopardi et al, 2003; Schmid et al, 2009; Schmid et al, 2010) as certain regions in the extrastriate visual cortex may have direct connections with subcortical nucleus and thus form parallel, V1-bypassing pathways contributing to the behavioral phenomenon of blindsight. A recent fMRI study indicated that direct LGN projections to the extrastriate cortex may play a critical role in mediating post-lesion residual vision (Schmid et al, 2010). However, all experimental evidence supporting their suggestions were collected one year (in cats) or at least one month (in monkeys) after lesion surgery, and therefore could not exclude the possibility that the postlesion residual vision (blindsight) and neuronal activities

\section{References:}

Azzopardi P, Fallah M, Gross CG, Rodman HR. 2003. Response latencies of neurons in visual areas MT and MST of monkeys with striate cortex lesions[J]. Neuropsychologia, 41(13): 1738-1756.

Barbur JL, Ruddock KH, Waterfield VA. 1980. Human visual responses in the absence of the geniculo-calcarine projection [J]. Brain, 103(4): 905-928.

Baseler HA, Morland AB, Wandell BA. 1999. Topographic organization of human visual areas in the absence of input from primary cortex[J]. $J$ Neurosci, 19(7): 2619-2627.

Bishop PO, Kozak W, Vakkur GJ. 1962. Some quantitative aspects of the cat's eye: axis and plane of reference, visual field co-ordinates and optics[J]. J Physiol, 163(3): 466-502.

Brainard DH. 1997. The psychophysics toolbox[J]. Spat Vis, 10(4): 433-436.

Bridge H, Thomas O, Jbabdi S, Cowey A. 2008. Changes in connectivity after visual cortical brain damage underlie altered visual function[J]. Brain, 131(6): 1433-1444.

Chino YM, Kaas JH, Smith EL III, Langston AL, Cheng H. 1992. Rapid reorganization of cortical maps in adult cats following restricted deafferentation in retina[J]. Vision Res, 32(5): 789-796.

Collins CE, Xu XM, Khaytin I, Kaskan PM, Casagrande VA, Kaas JH. 2005. Optical imaging of visually evoked responses in the middle temporal area after deactivation of primary visual cortex in adult primates[J]. Proc Natl Acad Sci USA, 102(15): 5594-5599.

Cowey A. 1962. Visual field defects in monkeys[J]. Nature, 193(4812): 302.

Cowey A, Stoerig P. 1991. The neurobiology of blindsight[J]. Trends Neurosci, 14(4): 140-145.

Cowey A, Stoerig P. 1995. Blindsight in monkeys[J]. Nature, 373(6511): 247-249.

Cowey A, Stoerig P. 1997. Visual detection in monkeys with blindsight[J]. Neuropsychologia, 35(7): 929-939.

Eysel UT, Schweigart G, Mittmann T, Eyding D, Qu Y, Vandesande F, Orban G, Arckens L. 1999. Reorganization in the visual cortex after retinal and cortical damage[J]. Restor Neurol Neurosci, 15(2-3): 153-164.

Girard P, Bullier J. 1989. Visual activity in area V2 during reversible inactivation of area 17 in the macaque monkey[J]. J Neurophysiol, 62(6): 1287-1302.

Girard P, Salin PA, Bullier J. 1991a. Visual activity in areas V3a and V3 during reversible inactivation of area $\mathrm{V} 1$ in the macaque monkey[J]. $J$ Neurophysiol, 66(5): 1493-1503. they observed in the higher visual cortical areas were created by visual pathways or circuits that reorganized after lesions of primary visual cortex. As demonstrated by a fMRI study in a patient with V1 lesions, neuronal response activation occurred first in the higher-tier visual areas V5 and V4 and subsequently in the lower-tier areas $\mathrm{V} 2$ and $\mathrm{V} 3$, which supports the notion that post-lesion reorganization of visual pathways may be a main contribution to the blindsight (Schoenfeld et al, 2002).

In summary, our results suggest that sparing of vision following lesions of primary visual cortical areas may be attributed not only to direct connections between subcortical nucleus and higher visual cortical areas, but, more importantly, to visual pathways and networks that reorganize after lesion surgery.

Girard P, Salin PA, Bullier J. 1991b. Visual activity in macaque area V4 depends on area 17 input[J]. Neuroreport, 2(2): 81-84.

Girard P, Salin PA, Bullier J. 1992. Response selectivity of neurons in area MT of the macaque monkey during reversible inactivation of area V1[J]. J Neurophysiol, 67(6): 1437-1446.

Goebel R, Muckli L, Zanella F E, Singer W, Stoerig P. 2001. Sustained extrastriate cortical activation without visual awareness revealed by fMRI studies of hemianopic patients[J]. Vision Res, 41(10-11): 14591474.

Hua TM, Bao PL, Huang CB, Wang ZH, Xu JW, Zhou YF, Lu ZL. 2010. Perceptual learning improves contrast sensitivity of V1 neurons in cats[J]. Curr Biol, 20(10): 887-894.

Hua TM, Li GZ, Tang CH, Wang ZH, Chang S. 2009. Enhanced adaptation of visual cortical cells to visual stimulation in aged cats[J]. Neurosci Lett, 451(1): 25-28.

Hua TM, Li XR, He LH, Zhou YF, Wang YC, Leventhal AG. 2006. Functional degradation of visual cortical cells in old cats[J]. Neurobiol Aging, 27(1): 155-162.

Hubel DH, Wiesel TN. 1962. Receptive fields, binocular interaction and functional architecture in the cat's visual cortex[J]. J Physiol, 160(1): 106-154.

Huxlin KR. 2008. Perceptual plasticity in damaged adult visual systems[J]. Vision Res, 48(20): 2154-2166.

Illig KR, Danilov YP, Ahmad A, Kim CBY, Spear PD. 2000. Functional plasticity in extrastriate visual cortex following neonatal visual cortex damage and monocular enucleation[J]. Brain Research, 882(1-2): 241250.

Kaas JH, Krubitzer LA, Chino YM, Langston AL, Polley EH, Blair N, Heinen SJ, Skavenski AA, Schmid LM, Rosa MG, Calford MB, Tolias AS, Ecker AS, Siapas AG, Hoenselaar A, Keliris GA, Logothetis NK. 1990. Reorganization of retinotopic cortical maps in adult mammals after lesions of the retina[J]. Science, 248(4952): 229-231.

Kalil RE, Tong LL, Spear PD. 1991. Thalamic projections to the lateral suprasylvian visual area in cats with neonatal or adult visual cortex damage[J]. J Comp Neurol, 314(3): 512-525.

Lomber SG, MacNeil MA, Payne BR. 1995. Amplification of thalamic projections to middle suprasylvian cortex following ablation of immature primary visual cortex in the cat[J]. Cereb Cortex, 5(2): 166191. 
Lomber SG, Payne BR, Cornwell P, Pearson HE. 1993. Capacity of the retinogeniculate pathway to reorganize following ablation of visual cortical areas in developing and mature cats[J]. J Comp Neurol, 338(3): 432-457.

Mao YT, Hua TM, Pallas SL. 2011. Competition and convergence between auditory and cross-modal visual inputs to primary auditory cortical areas[J]. J Neurophysiol, 105(4): 1558-1573.

Mohler CW, Wurtz RH. 1977. Role of striate cortex and superior colliculus in visual guidance of saccadic eye movements in monkeys[J]. $J$ Neurophysiol, 40(1): 74-94.

Moore T, Rodman HR, Gross CG. 2001. Direction of motion discrimination after early lesions of striate cortex (V1) of the macaque monkey[J]. Proc Natl Acad Sci U S A, 98(1): 325-330.

Moore T, Rodman HR, Repp AB, Gross CG. 1995. Localization of visual stimuli after striate cortex damage in monkeys: parallels with human blindsight[J]. Proc Natl Acad Sci U S A, 92(18): 8215-8218.

Ouellette BG, Minville K, Boire D, Ptito M, Casanova C. 2007. Complex motion selectivity in PMLS cortex following early lesions of primary visual cortex in the cat[J]. Vis Neurosci, 24(1): 53-64.

Payne BR. 2004. Neuroplasticity in the cat's visual system: test of the role of the expanded retino-geniculo-parietal pathway in behavioral sparing following early lesions of visual cortex[J]. Exp Brain Res, 155(1): 6980 .

Payne BR, Lomber SG. 1998. Neuroplasticity in the cat's visual system Origin, termination, expansion, and increased coupling of the retinogeniculo-middle suprasylvian visual pathway following early ablations of areas 17 and 18[J]. Exp Brain Res, 121(3): 334-349.

Payne BR, Lomber SG, Macneil MA, Cornwell P. 1996. Evidence for greater sight in blindsight following damage of primary visual cortex early in life[J]. Neuropsychologia, 34(8): 741-774.

Pelli DG. 1997. The VideoToolbox software for visual psychophysics: transforming numbers into movies[J]. Spat Vis, 10(4): 437-442.

Peng QS, Zhou J, Shi XM, Hua GP, Hua TM. 2011. Effects of urethane on the response properties of visual cortical neurons in young adult and old cats[J]. Zool Res, 32(3): 337-342.

Poggel DA, Kasten E, Müller-Oehring EM, Bunzenthal U, Sabel BA. 2006. Improving residual vision by attentional cueing in patients with brain lesions[J]. Brain Res, 1097(1): 142-148.

Rosa MGP, Tweedale R, Elston GN. 2000. Visual responses of neurons in the middle temporal area of new world monkeys after lesions of striate cortex[J]. J Neurosci, 20(14): 5552-5563.

Rossion B, de Gelder B, Pourtois G, Guérit JM, Weiskrantz L. 2000. Early extrastriate activity without primary visual cortex in humans[J]. Neurosci Lett, 279(1): 25-28.

Rushmore RJ, Payne BR. 2004. Neuroplasticity after unilateral visual cortex damage in the newborn cat[J]. Behav Brain Res, 153(2): 557-565.

Rushmore RJ, Rigolo L, Peer AK, Afifi LM, Valero-Cabré A, Payne BR.
2008. Age-dependent sparing of visual function after bilateral lesions of primary visual cortex[J]. Behav Neurosci, 122(6): 1274-1283.

Schiller PH, Malpeli JG. 1977. The effect of striate cortex cooling on area 18 cells in the monkey[J]. Brain Res, 126(2): 366-369.

Schmid MC, Mrowka SW, Turchi J, Saunders RC, Wilke M, Peters AJ, Ye FQ, Leopold DA. 2010. Blindsight depends on the lateral geniculate nucleus[J]. Nature, 466(7304): 373-377.

Schmid MC, Panagiotaropoulos T, Augath MA, Logothetis NK, Smirnakis SM. 2009. Visually driven activation in macaque areas V2 and V3 without input from the primary visual cortex[J]. PLoS One, 4(5): e5527.

Schoenfeld MA, Noesselt T, Poggel D, Tempelmann C, Hopf JM, Woldorff MG, Heinze H J, Hillyard SA. 2002. Analysis of pathways mediating preserved vision after striate cortex lesions[J]. Ann Neurol, 52(6): 814824.

Schoenfeld MA, Noesselt T, Poggel D, Tempelmann C, Hopf JM, Woldorff MG, Heinze HJ, Hillyard SA. 2002. Analysis of pathways mediating preserved vision after striate cortex lesions[J]. Ann Neurol, 52(6): 814824

Shupert C, Cornwell P, Payne B. 1993. Differential sparing of depth perception, orienting, and optokinetic nystagmus after neonatal versus adult lesions of cortical areas 17, 18, and 19 in the cat[J]. Behav Neurosci, 107(4): 633-650.

Silvanto J, Cowey A, Lavie N, Walsh V. 2007. Making the blindsighted see[J]. Neuropsychologia, 45(14): 3346-3350.

Smirnakis SM, Brewer AA, Schmid MC, Tolias AS, Schüz A, Augath M, Inhoffen W, Wandell BA, Logothetis NK. 2005. Lack of long-term cortical reorganization after macaque retinal lesions[J]. Nature, 435(7040): 300-307.

Stoerig P, Cowey A. 1997. Blindsight in man and monkey[J]. Brain, 120(3): 535-559.

Stoerig P, Cowey A. 2007. Blindsight[J]. Curr Biol, 17(19): R822-R824.

Tong F. 2003. Primary visual cortex and visual awareness[J]. Nat Rev Neurosci, 4(3): 219-229.

Weiskrantz L. 2004. Roots of blindsight[J]. Prog Brain Res, 144: 227-241.

Weiskrantz L, Warrington EK, Sanders MD, Marshall J. 1974. Visual capacity in the hemianopic field following a restricted occipital ablation[J]. Brain, 97(1): 709-728.

Zeki S, Ffytche DH. 1998. The Riddoch syndrome: insights into the neurobiology of conscious vision[J]. Brain, 121(1): 25-45.

Zepeda A, Sengpiel F, Guagnelli MA, Vaca L, Arias C. 2004. Functional reorganization of visual cortex maps after ischemic lesions is accompanied by changes in expression of cytoskeletal proteins and NMDA and GABAA receptor subunits[J]. J Neurosci, 24(8): 18121821.

Zhou J, Shi XM, Peng QS, Hua GP, Hua TM. 2011. Decreased contras sensitivity of visual cortical cells to visual stimuli accompanies a reduction of intracortical inhibition in old cats[J]. Zool Res, 32(5): 533-539. 